\title{
CSR AND THE LEGITIMACY OF BUSINESS IN TRANSITION ECONOMIES: THE CASE OF RUSSIA
}

\author{
A.Kuznetsov*, O.Kuznetsova and R.Warren \\ Published in Scandianvian Journal of Management, 25(1):37-45, 2009. \\ DOI: $10.1016 /$ j.scaman.2008.11.008
}

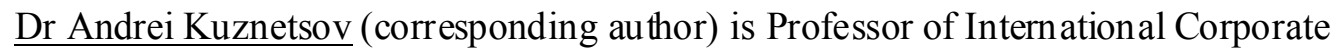

Social Responsibility, Lancashire Business School, University of Central Lancashire,

Greenbank Building, PRESTON, PR1 2HE, UK. Tel: +44 1772894695.

E-mail:akuznetsov@uclan.ac.uk

Dr Olga Kuznetsova is Senior Lecturer at the Manchester Metropolitan University Business School, UK.

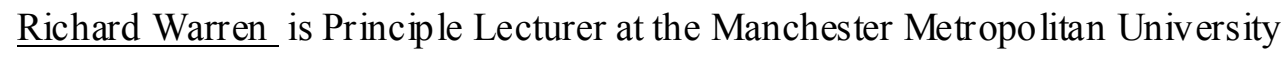
Business School, UK. 


\title{
CSR AND THE LEGITIMACY OF BUSINESS IN TRANSITION ECONOMIES: THE CASE OF RUSSIA
}

\begin{abstract}
:
In this paper we attempt to investigate the attitudes towards their perceived social responsibility on the part of the executives of a sample of medium and large Russian companies. Our empirical study is based on an original survey of executive managers of 500 industrial enterprises in almost all regions of Russia. We designed our questionnaire using as a starting point some important conclusions made by theorists who analysed the development of CSR in mature capitalist economies. Our objective was to probe whether the reaction by Russian managers would be in line with expectations grounded in western theoretical constructs, in particular the concept of business legitimacy. To preview our findings, we got evidence of a discrepancy between anticipated and actual attitudes. This result led us to consider a range of economic, social and political factors in the search for an explanation.
\end{abstract}

Keywords: corporate social responsibility, legitimacy, social trust, Russia. 


\section{CSR AND THE LEGITIMACY OF BUSINESS IN TRANSITION ECONOMIES: THE CASE OF RUSSIA}

All systems of property need legitimation if they are not to be seen as the exercise of power and greed.

(Moran, 2001: 277)

\section{Introduction}

Over the past years corporate social responsibility (CSR) has become a major conceptual and practical issue in the West. Russia, the largest post-communist economy in the world, has not stayed immune to this trend either. In 2003 alone no less than six major international conferences on CSR took place in Moscow, tending practical advice to the target audience of firm managers and government officials. In the same year President Putin called on corporations to increase their effort in the field of CSR at the annual meeting of the Russian Union of Industrialists and Entrepreneurs, the call that has been repeated by him many times since. Some large Russian companies, in particular those seeking an international status, were quick to respond and announced various steps in the direction of greater transparency, community support, environmental reporting, etc. These are the so-called "blue chip" firms, a rather small group of super large firms operating in oil extraction and other lucrative industries. Highly visible, they attract considerable attention, but they are not representative of the majority of firms in the Russian economy. Most firms in Russia are medium to large enterprises, employing between 300 and 5,000 workers. ${ }^{1}$ They enjoy no exclusivity, but remain the backbone of the national economy. Yet preciously little is known about their stance in regards to CRS.

\footnotetext{
${ }^{1}$ In 2000 establishments with less than 50 workers employed $1.4 \%$ of all labour force in Russia, 51-100 $2.7 \%, 101-200-7.1 \%, 201-500-16.2 \%, 501-1000-15.2 \%$, establishments with more than 1000 workers 57.3\% (Obzor zanyatosti v Rossii. Vypusk 1 (1991-2000). Moscow: Bureau of Economic Analys is. 2002:64).
} 
In this paper we attempt to fill in this gap and investigate the attitudes towards their perceived social responsibility on the part of the executives of a sample of medium and large Russian companies. Our empirical study is based on an original survey of executive managers of 500 industrial enterprises in almost all regions of Russia. In terms of size, sector affiliation and methods of privatization this sample, compiled on our behalf by the Russian Economic Barometer, an independent research centre located in Moscow, is reasonably representative of the whole population of Russian medium to large-size industrial firms. ${ }^{2}$ We received 129 replies, securing a respectable response rate of $26 \%$ for this type of survey.

Our analysis has a strong comparative element that is reflected in the organisation of this paper. We designed our questionnaire using as a starting point some important conclusions made by theorists who analysed the development of CSR in mature capitalist economies (section 2). Our objective was to probe whether the responses of Russian managers would be in line with expectations grounded in western theoretical constructs, in particular the concept of business legitimacy. To preview our findings, we found evidence of a discrepancy between anticipated and actual attitudes (section 3). This result led us to consider a range of economic, social and political factors in the search for an explanation (section 4). The last section summarizes the findings and draws some conclusions.

\section{Conceptual background}

CSR is addressed by many disciplines, but even within the management literature there are numerous definitions of and a variety of perspectives on CSR (for literature overview see Vogel, 2005; Lockett, Moon \& Visser, 2006; McWilliams, Siegel \& Wright, 2006). Under

\footnotetext{
${ }^{2}$ More details on the sample population used by REB can be found on the official web-page of the Institute of World Economy of the Russian Academy of Sciences on http:/www.imemo.ru/ru/period/barom/.
} 
these circumstances the necessary point of departure for any CSR related analysis is to establish its conceptual parameters. In defining CSR for the purpose of this study we follow a tradition in the literature (McGuire, 1963; Davis, 1973; Carroll, 1979; McWilliams and Siegel, 2001) that identifies CSR as situations in which the firm intentionally goes beyond compliance with the requirements of the law for the benefit of some social or environmental good. As Waldman and colleagues put it, "CSR [is] actions that go beyond the immediate legal requirements of the firm" (Waldman, de Luque, Washburn \& House, 2006: 824). As it might be anticipated, this definition has its advantages and disadvantages. First, it focuses attention on what we believe is an essential quality that distinguishes the pursuit of CSR activity from other business functions: rather than describing the social performance of corporations it provides meaningful criteria for delineating CSR actions - they should be voluntary and they should go beyond statutory norms. On the other hand, it is far from being exhaustive and often leaves the exact position of the dividing line between a CSR and non-CSR activity open for interpretation. One reason is the impact of globalisation and the related is sue of the extent to which the proposed definition allows for possible double standards. There are still parts of the world, some transition and developing countries in particular, in which the rule of law is weak and even basic public regulations are poorly developed. As a result a case can be made that even when a transnational corporation, operating in such an environment, exceeds the requirements of the law, this may still not be enough to constitute the act of CSR because it falls within the realm of minimal expected norms of behaviour in most countries in which this corporation has business interests. This raises a point relevant to the issues we consider in this paper: should it be expected that local and international firms are to demonstrate similarities in their attitude to the CSR agenda? A different but also relevant set of conceptual complications emerges from the well documented fact that many legal norms 
are ambiguous, which may result in a discrepancy between the letter and the spirit of the law. Indeed, from a formal point of view, acting in accordance with the letter of the relevant regulations is outside the domain of CSR, but what about obeying the spirit of the law? It may well be the case that in order to comply with the latter the firm may need to be seen to go beyond statutory requirements, but whether this would represent the act of CSR may be open to discussion. Finally, yet another challenge to this definition evolves from the growing practice in many developed countries to introduce "voluntary" good practice guidelines for companies seeking to meet minimum local expectations for CSR, which, in fact, progressively eliminate the "free will" component of CSR actions and turn them into a normative requirement. ${ }^{3}$

Normally we would not expect the definition of a category to explain why this category exists. The chosen working definition of CSR, however, provides a good pointer as to where the motivation for CSR comes from. It implies that the corporation has not only economic and legal obligations formalized in laws, regulations, statutes, etc, but also certain responsibilities to the society that extend beyond these normative obligations. In other words, CSR suggests the existence of an implicit social contract in which business is accountable to society's expectations or demands. Responding to this notion many authors have adopted legitimacy theory as a conceptual master-key to the CSR phenomenon (Gutherie and Parker, 1989; Mitchell, 1989; Warren, 1999; Woodward, Edwards and Birkin, 2001; Deegan, Rankin and Tobin, 2002; Warren, 2004; Branco and Rodrigues, 2006; Kuznetsov and Kuznetsova, 2006; McWilliams, Siegel and Wright, 2006). In line with Slim (2002), for our purposes legitimacy might be specified as a particular status with which an organisation is imbued and perceived at any given time that enables it to function

\footnotetext{
${ }^{3}$ For example, in May 2001 France mandated that companies quoted on the French stock exchange would have to present an annual report on their social and environmental performance (Fombrun, 2005).
} 
with the general consent of people and their groups, formal and informal organisations and governments that constitute the social environment in which it operates. In a similar vein, legitimacy may be also described as a generalised perception that the actions of the firm are desirable, proper or appropriate within some socially constructed system of norms, values, believes and definitions (Suchman, 1995). In this context CSR presents itself as an act of legitimisation.

The conception of legitimacy comes from political science, but it must be noted that some of the popular explanations of CSR that seem to be coming strictly from a business and economic perspective are in essence not too different from the legitimacy approach or incorporate some of its elements. Thus, the stakeholder theory of CSR links the success of companies with their ability to main tain trustful and mutually respectful relations with such constituents as customers, suppliers, employees, the general public and the government. Inevitably, relations with some of them are regulated by informal, morally defined norms rather than proper contracts. In other words, the stakeholder theory responds to the interrelationship between business and society, which is indeed very close to the key assumptions of the legitimacy theory. Similarly, there is an apparent link between the latter and another popular approach to CSR, the resource-based-view-of-the-firm (RBV). This view presumes that firms are bundles of heterogeneous resources and capabilities that are imperfectly mobile across firms and as such may constitute a source of sustainable competitive advantage. Hart (1995) and later McWilliams and Siegel (2001) applied this concept to CSR, considering a situation in which a company gets an advantage over competition by adding to its product some 'social' attribute or feature, which is valued by consumers/stakeholders. These attributes, it is argued, may be intangible but are consequential nonetheless because they manifest deliberate adherence to socially accepted 
and expected behaviours. The interpretation of resource as an ability to meet certain societal expectations contains an obvious cross-reference between the RBV theory of CSR and legitimacy. All in all, the concept of legitimacy probably succeeds the most in revealing the feature that is common, in our opinion, to all interpretations of CSR: the acknowledgement that in return for the ability to function business is subjected to social expectations and constraints that urge it to go beyond statutory norms.

Legitimacy is rooted in public presumption, making it an elusive quality, but this does not mean that firms cannot take steps that generate legitimacy. More and more firms see strategic value in developing and projecting a caring image that is critical to building up an organisation's reputation (Burke and Logson, 1996; Key and Popkin, 1998; McWilliams, Siegel and Wright, 2006). This is normally accomplished by reorienting CSR from a sporadic activity of an altruistic nature, like philanthropy, to a strategic function tied to more general organisational goals such as increasing profit or strengthening intangible assets (reputation, brand, etc). Legitimacy theory assumes that firms will make a rational and pragmatic strategic response to the public expectations in order to maintain some sort of social compact with society. Such a response is motivated by the realisation that compliance with societal expectations is necessary to safeguard some space for the freedom of action of business in the pursuit of profit. This implies that although it is not impossible for firms to engage in CSR on largely moral or ethical grounds, normally they do so to enhance corporate profit or shareholder gain. As Mitchell famously wrote, “corporate social responsibility remains businessmen's preferred response to threats to corporate power" (Mitchell, 1989:144). This "enlightened self-interest" thesis has been further developed by Jones (1995), Mahoney (1997) and Lawrence, Weber and Post (2005). According to Heal (2004), the contribution of CSR to economic performance is 
that it helps the market to align corporate profits and social costs. This contribution may come about in a number of ways, two of which, we believe, are especially relevant to the situation in post-communist countries. These are the projection of the positive image of corporations and, in particular, removing a strain in relations between corporations and their stakeholders that, in Russia, is rooted in mass privatisation of mid-1990s.

According to the literature, even in countries with a long and uninterrupted tradition of democracy the privatization of once public assets creates unique legitimisation requirements because it is usually accompanied with the provision of some concessions and privileges to the new owners at a cost to the public that require justification (Moran, 2001). In Russia privatisation turned out to be a particularly messy and murky affair that traumatised many Russians psychologically and hurt them financially, and still is widely regarded as deeply unfair. Public opinion polls indicate that more than a decade after the reforms started in Russia the societal acceptance of the market system is still an issue, one of the reasons being that corporations have failed to acquire the necessary status of legitimacy and respectability with major sections of society (see Pipes 2004 for the overview of the Russian public opinion). As a result the image of numerous corporations in Russia is tainted with the stigma of fraud, corruption and other forms of antisocial behaviour. As late as August 2006 a poll revealed that $44 \%$ of Russians thought that the activities of big business were detrimental to the interests of the country, $76 \%$ were in favour of a revision, full or partial, of the results of privatisation and 58\% supported an increase in the economic role of the state (Levada-Centre, 2006). Consequently there is an achingly unresolved matter of businesses facing the challenge of achieving acceptance from the wider society and needing to find ways to improve their legitimacy, particularly in those cases where the wealth was not created but merely transferred to others. 
Mutual suspicion in Russia between the people, business and the state is ripe. The people see the so-called oligarchs as usurpers of public wealth and politicians as their accomplices. In turn, politicians are weary of oligarch s' political aspirations while the later fear state interventionism. When the government tries to fight economic crime this causes suspicion that they are picking on political opponents; when big business starts to spend a lot of money on charity politicians suspect that oligarchs seek to create an alternative political powerbase. Lack of mutual trust is an issue that jeopardises the prospect of national economic recovery at present in Russia. A leading Russian economist claims that the restoration of trust is the principal issue facing the country (Shastitko, 2003). The Russian Economic Development Minister has commented that "The gradual slowdown of the economic growth pace we are witnessing now is due to the slowdown of reforms and low level of trust between business and authorities" (Johnson's Russia List 9039, 28/01/05).

It is not difficult to see, therefore, why, following the logic of the legitimacy concept, Russian firms may be expected to find en gagement in CSR rewarding. First, they have to overcome the unfavourable image they have in the eyes of public opinion caused by messy privatisations, confusing and inconsistent economic policies, the dismantling of the traditional system of social services, the contraction of the economy, mass impoverishment, and a misinterpretation of capitalist values. Second, they are facing the challenge of demarcating their territory in relations with the state. Many experts argue that for historical, geographical, cultural and political reasons the Russian economy is particularly prone to state control (Hellman, 1998; Robin son, 2000; Lynch, 2002). As a countermeasure, some commentators predict that corporations which self-regulate may 
avoid government interference in certain areas and so win favourable regulatory treatment compared to others, as the state can be expected to interpret socially responsible behaviour as a sign of competence on the part of corporations (Gabarro, 1978; Mitchell, 1989).

This analysis of the concepts of corporate legitimacy and CSR, a synopsis of which is outlined in this section, provided us with propositions that we can test out against the data from our questionnaire. We wanted to find out whether Russian managers of large firms were as interested in CSR as their western counterparts; whether their understanding of the substance of CSR was similar to that predominant in the west; whether, in the conditions of low generalised trust or weak social capital, Russian firms would prioritise CSR as a means of increasing their legitimacy with stakeholders; and finally, whether interest in CSR by Russian corporations was motivated by a desire to achieve greater freedom from state intervention.

\section{The Study and Findings}

A cross-sectional, non-experimental descriptive survey research design was used to collect data from the sample. Following Aupperle, Carroll \& Hatfield (1985), Angelidis and Ibrahim (2004) the survey instrument adopts a forced choice format as especially functional in the corporate social responsibility research area because of its ability to limit a respondent's social desirability bias. The instrument was designed to collect information on managers' attitudes to CSR and the factors that determine this attitude. It consis ted of 18 survey questions, including two requesting answers on five point Likert agreement scales (e.g., 1 to $5=$ very unimportant to very important; strongly agree to strongly disagree), and three questions requesting information on the size and the legal form of the 
firm. To maintain anonymity of the respondents, they were not required to provide their name or their company's name.

The frequency analysis of responses reveals the following picture.

a. A considerable number of respondents do not regard CSR as topical in modern Russia. As many as $39.53 \%$ of respondents answered negatively to the question "Do you agree that the idea of CSR is consistent with the current social-economic conditions in Russia?"

b. CSR for many firms is a slogan rather that a strategy: $66 \%$ of respondents supported the following statement: "In most cases declarations by firms that they adhere to the principles of corporate social responsibility are in fact purely public relation exercises," whilst only $15.65 \%$ disagreed.

c. Managers tend to include in CSR activities (like paying taxes, creating employment, abid ing by the law) that should not be there according to the recognised definition of CSR as "activity that goes beyond standard legal requirements and contracts." In Table 1 the views of respondents are ranged according to the frequency of opinions expressed.

d. Respondents do not believe that active involvement in CSR will result in more freedom from state intervention: only $6.20 \%$ of responden ts think that socially responsible corporate performance will reduce regulatory oversight. However, $37.07 \%$ believe that it will contribute to better relations with central authorities and $62.93 \%$ - to relations with local authorities. 
e. Almost $50 \%$ of managers believe that their firm acts socially responsible but give very low marks to everybody else, in particular to the oligarchs.

f. CSR performance is not seen as an important influence determining the public image of the firm; financial results are (see Table 2).

g. Lack of financial resources is indicated as a major constraint. Firms also blame the state and the legal system for not providing enough incentives $(20 \%$ and $24 \%$ of respondents respectively). Interestingly, $14.5 \%$ of respondents reported "not enough interest on the part of stakeholders" as a hindrance to greater CSR.

\section{Discussion}

Summarising the responses, two results stand out with particular prominence. First, firms appear to embrace the policies of CSR as a means of legitimisation much less willingly than might be expected on the basis of accepted theory and in the context of a Russian business legitimacy crisis. Second, the interpretation of CSR by Russian managers differs in many respects from the Western rhetoric and conceptions of CSR. It may be asserted that the reasons for these features are likely to be overlapping and caused by the specific institutional context of the transitional period in the socio-economic development of the country.

The notion of CSR has emerged in developed capitalist countries, in which the rule of law and other formal and informal institutions, i.e., universal and explicit rules that allocate responsibility and set up behavioural boundaries (North, 1990), are firmly in place and provide the procedures and routines that allow for the resolution of economic conflict and 
thus offer a solid and cost-effective foundation for market transactions. In a modern society formal institutions operate in an impartial manner, providing for a transparent, stable and predictable economic setting (Rose, 1998). Under these circumstances a business has to operate according to accepted norms and this is not regarded as something worthy of special praise. Consequently, activities aimed at increasing legitimacy require proof of an extra effort on the part of the firm that goes beyond statutory requirements and demonstrates its recognition of and commitment to certain social expectations. From this point of view, for example, the popular choices of CSR activity by our respondents, such as paying taxes and abiding by the law, look distinctly out of line. They, however, fit well into the picture drawn in the literature that presents Russia as the country with a weak institutional environment, in which laws are abused, rules are either feeble or not enforced, and institutions are incomplete, tendentious and corrupt (Blanchard and Kremer, 1997; Black, Kraakman \& Tarasova, 1999; Buck, 2003; Kuznetsov and Kuznetsova, 2003). In this context CSR is likely to acquire new dimensions compared to a standard Western interpretation.

The situation with regard to taxation in Russia bears all the signs of institutional deficiency and provides a good example of circumstances that require a modification of the accepted view of CSR. During the communist era the taxpayers as well as tax authorities had no experience of modern taxation. Most taxpayers were unaccustomed to the notion of a tax burden when the old system was replaced by a new one based on western models. If we add into the equation a growing mistrust towards the government and its bureaucracy, it is not surprising that tax evasion emerged as an essential modus operandi when economic actors were confronted for the first time with explicit tax requirements (Martinez-Vazquez and $\mathrm{McNab}, 2000$ ). The situation was exacerbated by admin is trative incompetence: "tax 
liabilities have often been negotiated rather than determined by law. To make matters worse, tax authorities were allowed to impose highly punitive penalties which often bear no relationship to the actual tax liability..." (Pogorletskiy and Sollner, 2002:157). Businessmen were outraged by high tax rates and the cost of complying with all the regulations, which they believed were lethal for their businesses, and found it necessary to move their operation into the parallel or "shadow" economy. According to the Expert Institute of the Russian Union of Industrialists and Entrepreneurs (Yegiazorova, 1997), in the late 1990 s up to $75 \%$ of firms practiced concealment of a considerable proportion of income, the placement of capital abroad, and the evasion of excise duty and smuggling as the most common forms of "shadow" activity. Another report claimed that eight firms out of ten considered tax evasion and fraud a viable business tactic (Dushatski, 1998). The state responded by introducing in 2001, 2002 and 2004 a three stage reform making taxes more acceptable and "user-friendly" for taxpayers and creating an environment in which paying taxes would make more economic sense to taxpayers than meeting the cost of avoiding them. According to some estimates, about 30 billion roubles (US\$1billion) of income were expected to be legalised (ITAR-TASS, 11.06.2004). Disappointingly, the reform has failed to achieve all its objectives. Thus, in 2003 just $0.002 \%$ of the labour force declared the annual income of over 600,000 roubles (about $\$ 1,800$ per month) whilst experts estimated the number of employees that earned over $\$ 2,000$ per month at least at $5 \%$ of the labour force. As late as 2004, opinion polls revealed that about a third of respondents believed that evading taxes was appropriate whilst more than a half of respondents did not condemn tax dodgers or were indifferent to them (Interfax, 01.11.2004). The social sphere that relies particularly heavily on budget funds feels the whole brunt of poor tax collection. In fact the share of social payments in the GDP has been falling progressively ever since 2001 . 
This example demonstrates that in economies with a weak institutional environment, unlike modern western economies, for many firms just abiding by the law may well become a manifestation of CSR in a context where non-compliance is a norm and statutory requirements are often little more then a pretence as the authorities and institutions are unable to credibly enforce them. In this situation, we believe, emphasis on the condition that the firm should go beyond the immediate legal requirements as a criterion of CSR calls for modification. The more appropriate formulation should refer to enforceable laws. The other two parameters, deliberateness and contribution to some social good, maintain their validity.

As mentioned earlier, the survey failed to support our hypothesis regarding the perceived relationship between CSR activity and the legitimisation of business. On the one hand, $52 \%$ of the respondents demonstrated awareness of the fact that the society had certain (yet unfulfilled) expectations vis-à-v is their firms. On the other hand, they put little value on CSR as both a means to increase the prestige of the firm in the eyes of the public and as an opportunity to earn some freedom of action from the state. Chart 1 illustrates the responses to the question, in which managers were asked to evaluate the impact of a range of factors on the public perception of the firm (1-minimal impact; 5-maximum impact). Financial results were most widely rated as having the highest impact with the mean of 4.26. All three characteristics related to CSR received only moderate ranking with environmental practices achieving the mean of 3.25 , philanthropy and charitable activities -3.26 , and "showing responsibility to society at large" - the mean of 3.16 . What attracts attention is the configuration of the spread of opinions regarding this last parameter, which is very flat. This is most likely to happen either when respondents are unsure about the meaning of the 
question or there is no prevailing view on the issue, or both. In any case, this pattern of distribution may be interpreted as a sign that the managers participating in our survey in general did not see the development of a policy on CSR as a priority.

Respondents demonstrated a remarkable unanimity in rejecting the proposition that greater involvement in CSR would produce more freedom from state interference. This supports the thesis expressed in the literature that although many businesses have now been separated from the state, this separation is new and at a tentative stage in the transition process in many respects (Ledeneva, 2006). Although many as sets and businesses were privatised in the $1990 \mathrm{~s}$, the signs are that government interference in strategic assets and large corporations is increasing once again. One of the reasons is that the state faces the challenge of legitimacy itself as a backlash against the role it played in assisting the business oligarchs to enormously enrich themselves in the privatization programme and obtain huge influence. The Putin government has sought to re-build its authority over these strategic corporations to reassure the public that they will make these businesses more mindful of public welfare and for strategic policy reasons in Russia's international relations. One consequence is the attempt by the state to take the initiative of promoting CSR on its own terms, emphasising the responsibility of firms over social issues which are traditionally covered by the state. The efforts of the state are focused on large strategic corporations, which are called upon to put in place CSR policies and become more transparent and accountable to the public and international investors and thus contribute to improving the legitimacy of both the state and these strategic corporations. In this respect, the adoption of Western rhetoric and conceptions of CSR is an important part of this political strategy and is an example of institutional isomorphism. However, the situation confronting the majority of Russia's business community is very different and our study of 
large and medium sized businesses indicates that Western CSR notions have little purchase or relevance for the managers of these firms because they are unlikely to be used as strategic tools of the state's political and international policies. The managers of these firms are convinced that, as follows from our survey, the state is not likely to trade intrusive control for greater business self-regulation in the foreseeable future.

One probable explanation of the evidence that Russian managers appear to attach less importance to some elements of CSR that are traditionally high on the agenda of western corporations is that the legitimacy issue in the Russian context has a different focus. Opinion polls still demonstrate that the Russian public tends to deny that business people possess such virtues as morality, integrity, talent or hard work. Instead, many Russians regard dishonesty and connections as the keys for business success in their country (Kuznetsov and Kuznetsova, 2005). In turn, it is not uncommon for members of the business community to maintain that the current economic and institutional set-up in the country precludes honest ways of making money (Latynina, 1999). In contrast to other countries, in Russia there is a considerable degree of ambiguity regarding some most fundamental issues including ownership rights, the role of contract, the concept of legality, the notion of business ethics, etc, contributing to the unpopular image of the entrepreneur and businessman. This suggests that the legitimacy challenge for Russian business outside of the largest strategic corporations is very much to establish a consensus where business can be seen as an honourable and acceptable activity that will command respect and support from the wider society.

\section{Conclusions}

The key finding of our study is that there is a notable variance in the position of Russian 
companies towards CSR. Presenting a positive social image is more likely to be important to those of them with high public visibility. There is a handful of super large corporations, operating in oil extraction and other lucrative industries, that occupy a strategic position in the national economy. They enjoy special relations with the state and seek to attract financial resources from foreign and international markets to support their expan sion. They can be seen participating in social investments and philanthropic actions, inserting CSR references in their annual reports and making other efforts to project the image of a socially caring business in order to facilitate international recognition and to further their contacts with the state. Regarding the nature of the latter one top manager stated: "Companies are prepared for any form of social responsibility as long as their property is protected" (Denisov and Sitnina, 2005).

By contrast, those large and medium sized firms that do not have the benefit of an exclusive relation ship with the state are far less committed to CSR. Our survey reveals that almost half of respondents believe that the conditions are not yet right for them to take on more social responsibility. Lack of financial resources is indicated as a major constraint. Firms also blame the state and the legal system for not providing enough incentives $(20 \%$ and $24 \%$ of respondents respectively). Characteristically, some managers are concerned that greater expenditure by companies on CSR may encourage the state to increase taxes.

Our results are in line with those obtained by earlier studies. The survey "The Social Portrait of the Russian Firm" undertaken by the Association of Russian Managers (Moscow) in 2003 revealed that firms favoured those CSR actions that related to profitmaximising activities while environment protection and community projects were not marked as priorities (Vestnik assotsiatsyi menedzherov, 2003, October, No.1: 27). Another 
study by the Association found that only $12 \%$ of the 300 top managers surveyed believed that CSR activities could result in better relations with the state (Litovchenko and Korsakov, 2003: 51).

Theorists maintain that business enhances its legitimacy when it conforms to institutional constrains (Palmer and Biggart, 2002). The mixed picture of attitudes held by Russian managers towards CSR brought to light by our study reflects, in our opinion, the many controversies and ailments of Russian post-communist transition related to the current stage in the development of formal and informal institutions in the country. Legitimacy theory postulates that to operate successfully companies need to take into account society's concepts of business responsibility and what society perceives to be "appropriate" actions. Legitimacy itself, however, is not a fixed set of moral norms. It develops and changes over time following alterations in the perception of what is appropriate held by the majority of people. This assumes the existence of a mechanism that conveys the attitudes of the society to the firm. As Woodward, Edwards and Birkin (2001: 387) indicate, it may be of an informal, morally-defined variety as regards some of the stakeholders with which the company interacts, compared with the more formal, and contractually-defined relationship it has with other stakeholders, particularly the owners. In both cases the presence of institutions that allow the gathering of valid information on economic actors, the monitoring of their performance and that will penalise opportunistic behaviour is critical. Weak institutions create the ambience of permissiveness; economic agents are not encouraged to act fairly because self-interested behaviour meets little resistance. Our survey suggests that in Russia some forms of communication between society and business have more impact on the latter than the other. The pre-eminent position of the state, reinforced under President Putin, makes businesses very sensitive to signals coming from 
this direction. The state has already captured the term CSR but promotes its interpretation in a way that emphasises the payment of taxes and the taking of responsibility over social issues which are traditionally covered by the state. ${ }^{4}$ At the same time large and medium firms appear to be less responsive towards CSR imperatives that come from the local community, NGOs, and social movements, etc. Building on North's notion that business practices that come into existence will reflect the opportunities provided by the institutional matrix, it may be assumed that the current "rules of the game," as institutions are sometimes defined, do not support the impact of the community, etc on the firm.

There is one other consequence of the weakness of the institutions that, as we see it, helps to explain the finding that Russian firms do not prioritise CSR as a means that increases their legitimacy with stakeholders. As was mentioned earlier, theory predicts that on the part of the firm interest in CSR may be motivated by the desire to substitute some forms of formal regulation by self-regulation and so win favourable regulatory treatment compared to others. However, it is sensible for the firm to make an extra effort only if the regulations are efficient, universally and fairly enforced and sufficiently stable, i.e., if there is no discrepancy between the declared and actual "rules of the game." If this is not the case, whatever the social expectations are, the rational economic actor will be discouraged from producing such an effort because formal regulations and relations have little currency. Thus, some international companies operating business units in countries with a low degree of economic freedom have found themselves in a position when it proved difficult to be seen to be doing the "right" things, no matter what they did (Woodward, Edwards \& Birkin, F., 2001). In the Wall-Street Journal's 2007 Index of Economic Freedom Russia is

\footnotetext{
${ }^{4}$ According to the data of the Association of Russian Managers many firms are reluctant to make public information on CSR because this may provoke ill-favoured attention from a variety of parties, rang ing from self-interes ted bureauc rats to criminals. Evidently, presidential blessing for the few is not a suffic ient impulse for the majority of large and medium firms to acknowled ge the ir involvement in the field of CSR.
} 
ranked 39th out of 41 countries in the European region. Its main weaknesses are identified as rampant corruption, the insecurity of property rights, arbitrary law enforcement and bureaucratic inconsistency. These are not the conditions that are likely to make Russian firms receptive to the values of CSR on a voluntary basis.

It may also be argued that the socio-economic situation in Russia creates yet more obstacles for local firms if they wish to embrace western notions of CSR because by doing so they may sow the seeds of confusion about the purpose of business in Russian society. The scepticism of Russian managers towards the state's call for them to embrace CSR and a wider set of social and environmental responsibilities may be a pragmatic response to the situation. The business model presently influential in large and medium sized Russia firms is one where business wishes to be seen as separate from the state and its wider social commitments. This is a view where business is seen as a distinct and limited endeavour that has narrow and specific, but, nonetheless, important basic responsibilities. After all, if businesses have only relatively recently freed themselves from these wider social obligations and activities why would they wish to appear to be re-embracing them again and risk giving the misleading impression that business is once again becoming part of the state. The model of business legitimacy that will support large businesses, apart from those where the State seeks to retain its influence is, in our survey, one much more in tune with the views of the neo-liberal market theorists where business responsibilities to society are specific and limited. Its claim to legitimacy rests upon sticking to its sphere of operation and in delivering the prosperity that society needs. CSR in the Russian context is interpreted by Russian managers as much more about creating productive firms that provide real jobs and that generate wealth. By showing that business can act independently of the state, business people may be hoping to build the social legitimacy of business as an 
honourable and respectable occupation. If this were to be successful, this could be seen as a real achievement in the context of a society where 70 years of communist propaganda attempted to portray business as rapacious and immoral enterprise that exploited the working class and impoverished the third world. Our results may be interpreted as evidence that the business legitimacy challenge in the Russian large firm context is dealt with at the moment not so much through re-embracing welfare and social responsibilities but through demonstrating that business is a wealth creating function that is of benefit to society because it provides employment, incomes, taxes and shareholder wealth. By attempting to deliver on these basic, but to date, in the context of Russia, often neglected responsibilities, firms are hoping to gain a wider social support and some independence and freedom from state interference and lay down a marker separating themselves from the old way of doing things.

On the basis of this analysis it seems unlikely that CSR will spontaneously emerge in contemporary Russia as it has in the West. This may change if the state can take the initiative and underwrite and guarantee consistent, fair and enforceable rules and laws so that firms may follow their own inclination in the direction of CSR without fear. In this way the state may start the "virtuous circles," that inspire trust and the growth of social capital. The importance of this reform process cannot be overestimated.

\section{Acknowledgements}

The authors acknowledge the financial support provided by the British Academy under research grant LRG: 35419. 


\section{Bibliography}

Angelidis, J. and Ibrahim, N. (2004). An exploratory study of the impact of degree of religiousness upon an individual's corporate social responsiveness orientation. Journal of Business Ethics 51(2): 119-128.

Aupperle, K. E., Carroll, A. B. and Hatfield, J. P. (1985). An empirical examination of the relationship between corporate social responsibility and profitability. Academy of Management Journal 28(2): 446-463.

Black, B., Kraakman, R. and Tarasova, A. 1999. Russian Privatisation and Corporate Governance: What Went Wrong. Working Paper No.178, Stanford Law School.

Blanchard, O. and Kremer, M. 1997. Disorganization. Quarterly Journal of Economics 112(4): 1091-1126.

Branco, M.C. and Rodrigues, L.L. (2006) Communication of corporate social responsibility by Portuguese banks: A legitimacy theory perspective. Corporate Communications: An International Journal 11(3): 232-248.

Buck, T. 2003. Modern Russian corporate governance: convergent forces or product of Russia' his tory? Journal of World Business 38(4): 299-213.

Burke, L. and Logson, M. (1996). How Corporate Social Responsibility Pays Off. Long Range Planning, 29(4): 495-502.

Davis, K. (1973). The case for and against business assumption of social responsibilities. Academy of Management Journal 16(2): 312-22.

Denisov, A. and Sitnina, V. (2005). Dekadans-Kapital. Vremya Novostei, 03 February, No.17: 7-8.

Dushatski, L. (1998). Vzaimodeistvie predprinimatelei s uslovijami sredy. Sotsiologitcheskie issledovania No.1: 68-72. 
Gabarro, J. J. (1978). 'The development of trust, influence and expectations', in Athos A. G. and Gabarro J. J. (eds.) Interpersonal behaviors: Communication and understanding in relationships, Prentice Hall: Englewood Cliffs, NJ.

Heal, G. (2004). Corporate social responsibility - an economic and financial framework. Paper presented at the Annual Conference of the Monte Paschi Vita.

Hellman, J.S. (1998). Winners Take All: The Politics of Partial Reforms in Post-

Commun ist Transitions. World Politics 50: 203-34.

Fombrun, C.J. (2005). Building corporate reputation through CSR initiatives: Evolving standards. Corporate Reputation Review 8(1):7-11.

Index of Economic Freedom: Russia (2007). Available on: http://www.heritage.org/index/country.cfm?id=Russia

Jones, T. M. (1995). Instrumental stakeholder theory: A synthesis of ethics and economics: A survey. Academy of Management Review 20(2): 404-37.

Key, S. and Popkin, S. (1998). Integrating ethics into the strategic management process: doing well by doing good. Management Decision 6(5): 331-338.

Kuznetsov, A. and Kuznetsova, O. 2003. Institutions, Business and the State in Russia. Europe-Asia Studies 55(?): 907-922.

Kuznetsov, A. and Kuznetsova, O. 2005. Business culture in modern Russia: deterrents and influences. Problems and Perspectives in Management 2(2): 25-31.

Kuznetsov, A. and Kuznetsova, O. (2006) Closing the gap between big business and society in Russia: the role of corporate social responsibility. Paper presented at the British Academy of Management 2006 Conference, Belfast.

Latynina, Yu. (1999). Zapiski iz podpol'ia. Ekspert No.3: 31-33.

Lawrence, A.T., Weber, J. and Post, J.E. (2005) Business and Society:Stakeholders, Ethics and Public Policy. $11^{\text {th }}$ Edition, McGraw-Hill Irwin: Sydney. 
Ledeneva, A. V. (2006). How Russia Really Works, Cornell University Press: New York. Levada-Center (2006). Sotsial'no-politicheskaia situatsia v Rossii v avguste 2006 goda. Availabel on http://www.levada.ru/press/2006091302.html.

Litovchenko, S.E. and Korsakov, M.I. (eds) (2003). Korporativnaia sotsial'naia otvetstvennost': obshestvennye ozhidania. Asso tsiatsia menedzherov: Moscow.

Lockett, A., Moon, J. and Visser, W. (2006). Corporate Social Responsibility in Management Research: Focus, Nature, Salience and Sources of Influence. Journal of Management Studies 43(1): 115-36.

Lynch, A. (2002). Roots of Russia's economic dilemmas: liberal economics and illiberal geography. Europe-Asia Studies 54(1): 31-49.

Mahoney, R.J. (1997). Shareholders, stakeholders, and en lightened self-interest. Business \& the Contemporary World, IX(2): 325-36.

Martinez-Vazquez, J. and McNab, R.M. 2000. The tax reform experiment in transitional countries. National Tax Journal 53(2): 273-98.

McGuire, J.W. (1963). Business and Society, McGraw-Hill: New York.

McWilliams, A. and Siegel, D. (2001). Corporate social responsibility: a theory of the firm perspective. Academy of Management Review, 26: 117-27.

McWilliams A., Siegel D.S. and Wright, P.M. (2006). Corporate Social Responsibility: Strategic Implications. Journal of Management Studies 43(1): 1-18.

Mitchell, N.J. (1989) The Generous Corporation: A Political Analysis of Economic Power. Yale University Press: New Haven, CT.

Moran, M. (2001). The lost legitimacy: Property, business power and the constitution. Public Administration 79(2): 277-296.

North, D. (1990). Institutions, Institutional Change and Economic Performance. Cambridge: Cambridge University Press. 
Palmer, D. and Biggart, N. (2002). "Organizational Institutions” in J.Baum (ed.) Blackwell Companion to Organizations. Oxford: Blackwell, pp.259-280.

Pipes, R. (2004). Flight from freedom: what Russians think and want. Foreign Affairs 83(3): 9-15.

Pogorletskiy, A. and Sollner, F. (2002). The Russian tax reform. Intereconomics 37(3): 156-161.

Robinson, N. (2000). The economy and the prospects for anti-democratic development in Russia. Europe-Asia Studies 52(8): 1391-1416.

Rose, R., 1998. Getting Things Done in an Anti-Modern Society: Social Capital Networks in Russia. Social Capital Initiative Working Paper No. 6. World Bank: Washington DC.

Shastitko, A., 2003. Contribution to the round table discussion 'The legitimacy of privatisation and trust in the society, organized by the Liberal Mission Fund, Moscow, 14.10.2003. Available online at http://www.liberal.ru/sitan.asp? Num=407

Slim, H. (2002). By What Authority? The Legitimacy and Accountability of Nongovernmental Organisations. The Journal of Humanitarian Assistance. Available at: http://www.jha.ac/articles/a082.htm.

Suchman, M.C. (1995). Managing legitimacy: Strategic and institutional approaches. Academy of Management Review 20: 571-610.

Vogel, D. (2005). The Market for Virtue: The Potential and Limits of Corporate Social Responsibility. Washington, DC: Brooking Institution Press.

Waldman, D.A., de Luque, M.S., Washburn, N. and House, R.J. (2006). Cultural and leadership predictors of corporate social responsibility values of top management: a GLOBE study of 15 countries. Journal of International Business Studies 37: 823-37.

Warren, R. (1999). Company Legitimacy in the New Millennium. Business Ethics: a European Review, 8(4): 214-224. 
Warren, R. (2003). The Evolution of Business Legitimacy. European Business Review, 15(3): 153-163.

Woodward, D., Edwards, P. and Birkin, F. (2001) Some evidence on executives' views of corporate social responsibility. British Accounting Review, 33: 357-397.

Yegiazorova, I. (1997). Biznes priachetsia v teni. Rabochaya Tribuna, May 6, p.2. 
Table 1. Characteristics of CSR as perceived by Russian managers

\begin{tabular}{c|l|l|}
\hline Rank & \multicolumn{1}{|c|}{ Characteristic } & \multicolumn{1}{|c|}{ Frequency } \\
\hline 1 & looking after employees & 0.904 \\
\hline 2 & protecting the environment & 0.760 \\
\hline 3 & paying taxes & 0.704 \\
\hline 4 & being ethical with the stakeholders & 0.632 \\
\hline 5 & creating jobs & 0.608 \\
\hline 6 & contributing to charities & 0.584 \\
\hline 7 & $\begin{array}{l}\text { contributing to the welfare of the local } \\
\text { community } \\
7\end{array}$ & 0.576 \\
\hline 8 & obeying laws & 0.576 \\
\hline 9 & $\begin{array}{l}\text { adhaking a profit } \\
\text { business conduct }\end{array}$ & 0.395 \\
\hline
\end{tabular}

$\mathrm{n}=125$

Table 2. Characteristics of the firm that have the greatest impact on its public image as perceived by Russian managers (1-minimal impact; 5-maximum impact).

\begin{tabular}{c|l|c|c|}
\hline Rank & \multicolumn{1}{|c|}{ Characteristic } & Mean & $\mathrm{n}$ \\
\hline 1 & Financial results & 4.26 & 121 \\
\hline 1 & The reputation of the firm & 4.26 & 112 \\
2 & The reputation of the brand & 4.05 & 111 \\
\hline 3 & Identification and pursuit of & 3.95 & 109 \\
& opportunities & & \\
\hline 4 & The competence of managers & 3.89 & 115 \\
\hline 5 & Business ethics & 3.69 & 110 \\
\hline 6 & Labour practices & 2.75 & 116 \\
\hline
\end{tabular}


(b) Figure(s)

Chart 1

The impact of environmental practices on the public perception of the firm (1minimal impact; 5-maximum impact)

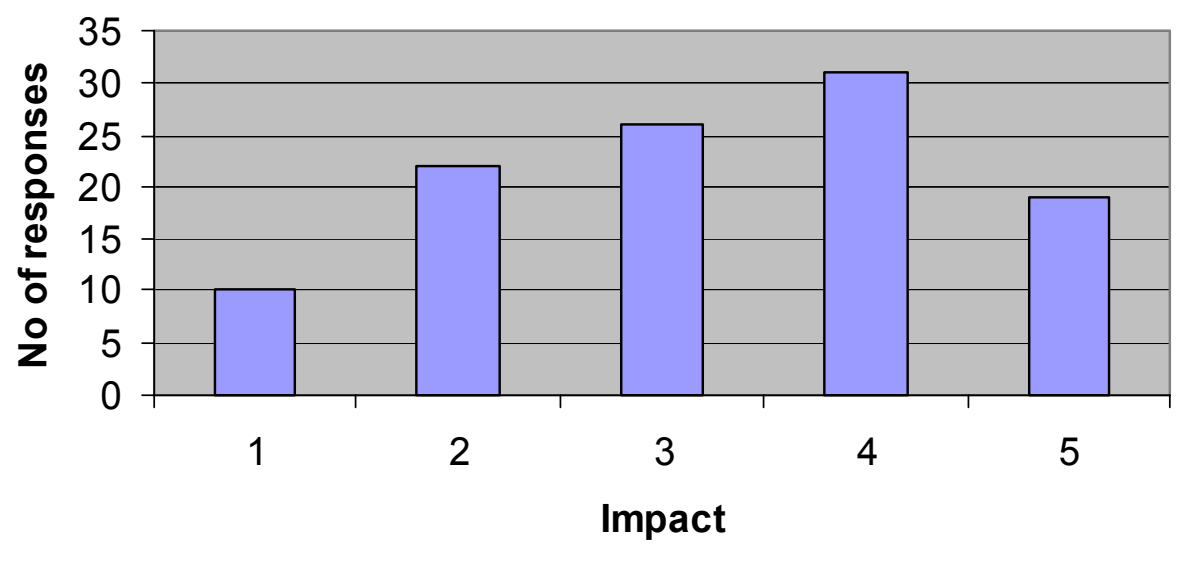

The impact of philanthropy and charitable activities on the public perception of the firm (1-minimal impact; 5-maximum impact)

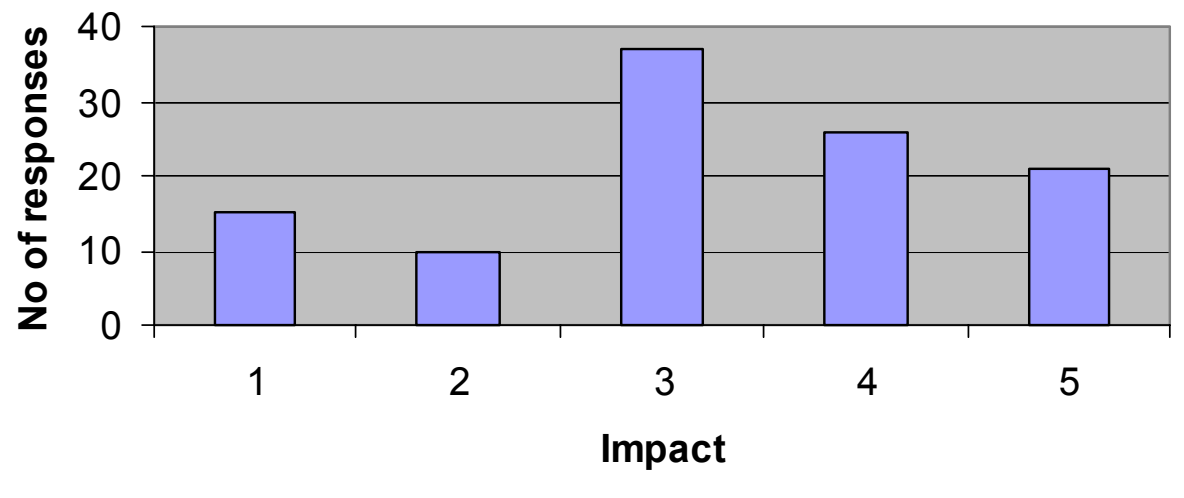


The impact of "showing responsibility to society at large" on the public perception of the firm (1-minimal impact; 5-maximum impact)

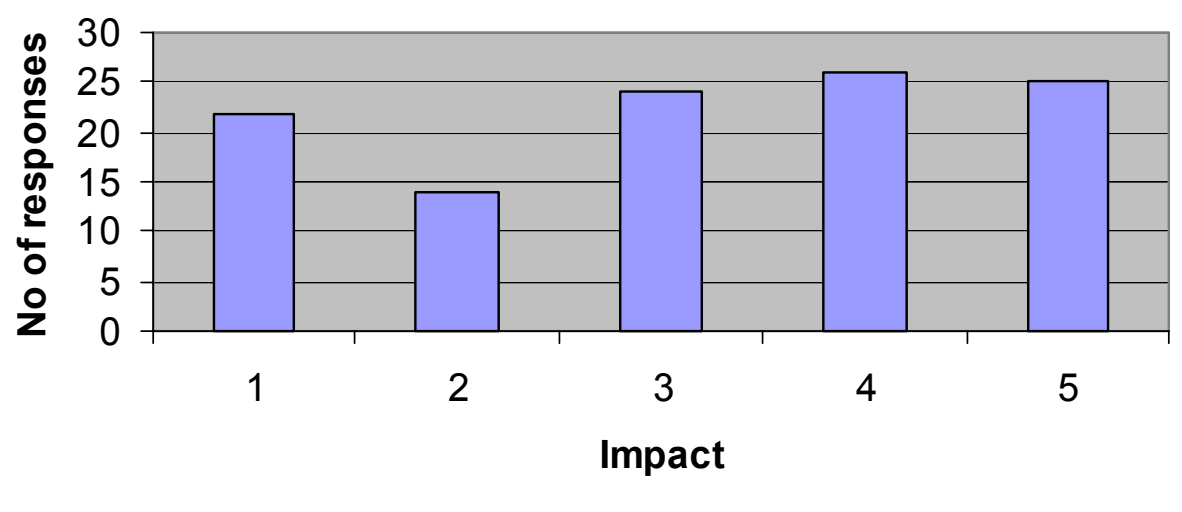

The impact of financial results on the public perception of the firm (1-minimal impact; 5-maximum impact)

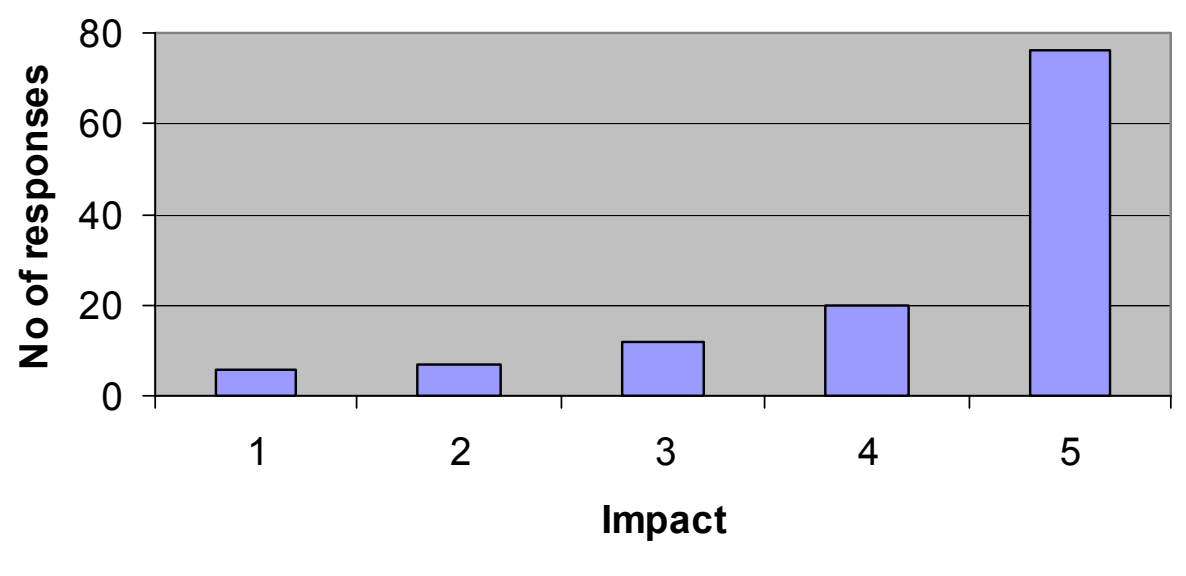

